\title{
ANALISIS KEBERLANJUTAN PERIKANAN TANGKAP SKALA KECIL DI KABUPATEN TEGAL JAWA TENGAH (TEKNIK PENDEKATAN RAPFISH)
}

\author{
Oleh : \\ Benny Osta Nababan ${ }^{1}$, Yesi Dewita Sari ${ }^{1}$ dan Maman Hermawan ${ }^{2}$
}

\begin{abstract}
ABSTRAK
Penelitian keberlanjutan perikanan tangkap skala kecil di Kabupaten Tegal, Jawa Tengah telah dilakukan pada tahun 2005 - 2006. Keberlanjutan perikanan tangkap ditentukan oleh interaksi beberapa aspek (dimensi) penting seperti dimensi ekologi, teknologi, sosial, ekonomi dan hukum-kelembagaan. Penelitian ini bertujuan untuk menentukan status perikanan tangkap skala kecil dalam perspektif keberlanjutan menurut dimensi ekologi, teknologi, sosial, ekonomi serta hukum-kelembagaan, serta mengidentifikasi kebijakan untuk mendukung keberlanjutan perikanan tangkap di Kabupaten Tegal. Teknik Rapfish adalah analisis kuantitatif yang digunakan dalam penelitian ini untuk mengevaluasi status keberlanjutan perikanan tangkap di lokasi penelitian. Pada dimensi ekologi, ekonomi, teknologi, dan hukum-kelembagaan di Kabupaten Tegal untuk semua alat tangkap yang diteliti dalam status kurang berkelanjutan baik untuk jaring rampus, bundes maupun payang gemplo. Studi ini menunjukkan bahwa dimensi ekologi merupakan dimensi yang memiliki skor paling rendah dengan skor kurang bahkan cenderung menjadi buruk dalam mendukung keberlanjutan perikanan tangkap skala kecil di perairan pantai Kabupaten Tegal. Studi ini juga berhasil mengidentifikasi atribut-atribut penting dan sensitif. Perbedaan status keberlanjutan berdasarkan alat tangkap di lokasi penelitian juga teridentifikasi dengan jelas berdasarkan atribut-atribut pendukungnya. Studi ini juga merekonfirmasi pentingnya keterpaduan aspekaspek bio-techno-socioeconomic dalam pengembangan pola pengelolaan perikanan.
\end{abstract}

Kata Kunci : status berkelanjutan, keberlanjutan, perikanan tangkap skala kecil, Rapfish

\section{Abstract : Sustainability Analysis of Small Scale Fisheries in Tegal District of Central Java (a Fish Approach). By Benny Osta Nababan', Yesi Dewita Sari', and Maman Hermawan ${ }^{2}$}

The research on sustainability of small scale fisheries in Tegal district, Central Java has been carried out. Fishery sustainability is determined by several interacting factors, such as ecology, technology, social, economic and legal-institution. The objective of this study was to determine the sustainability status of small scale fishery according to ecological, technological, social, economic, and legal-institutional dimensions. The second objective was to identify policy promoting for the capture fisheries sustainability. Sustainability of fishery in the coastal area of Tegal district analyzed quantitatively by Rap fish technique. Fishing gears, such as Jaring Rampus, Bundes and Payang Gemplo weren't in sustainable status from ecological, economic, technical and legal- institutional standpoints. The study showed that ecological aspect has the lowest score in order to support small scale fishery sustainability in the coastal water of Tegal. Differences in sustainability status are likely due to variations in main characteristic of the fisheries. Several sensitive attributes and recommendations in order to support fisheries sustainability, also identified in this study. This study reconfirms the need to apply comprehensive and integrated bio-technico-socioeconomic aspects in developing fisheries management.

\section{Keywords : Sustainable Status, Sustainability, Small Scale Fisheries, Rapfish}

\footnotetext{
${ }^{1}$ Peneliti Pada Balai Besar Riset Sosial Ekonomi Kelautan dan Perikanan, BRKP-DKP. JI. KS TUBUN Petamburan VI Slipi Jakarta 10260. Telp. (021) 53650162
}

${ }^{2}$ Dosen pada Sekolah Tinggi Perikanan, DKP 


\section{PENDAHULUAN}

Perikanan adalah salah satu sektor yang diandalkan untuk pembangunan masa depan Indonesia, karena dapat memberikan dampak ekonomi kepada sebagian penduduk Indonesia. Selain itu, produk perikanan adalah bahan makanan penting masyarakat pada umumnya, sehingga sektor perikanan menjadi salah satu sumber pendapatan negara disamping menjadi sumber mata pencaharian sebagain besar masyarakat di kawasan pantai terutama nelayan. Perikanan tangkap nasional masih dicirikan oleh perikanan tangkap skala kecil. Hal ini dapat dibuktikan dengan keberadaan perikanan tangkap di Indonesia yang masih didominasi oleh usaha perikanan tangkap skala kecil yaitu sekitar $85 \%$, dan hanya sekitar $15 \%$ di lakukan oleh usaha perikanan skala yang lebih besar (Hermawan, 2006). Perikanan tangkap skala kecil dapat diklasifikasikan ke dalam kondisi/karakter usaha dari nelayan sebagai operator usahanya. Dengan kata lain operator usaha perikanan tangkap skala kecil diklasifikasikan sebagai nelayan kecil (Hermawan, 2006).

Perikanan tangkap di Indonesia memerlukan pengelolaan yang terencana agar kegiatan perikanan tangkap skala kecil ini dapat berkelanjutan. Dengan memperhatikan karakteristik perikanan Pantai Utara Jawa Tengah khususnya kegiatan perikanan tangkap di Kabupaten Tegal serta adanya konsep penilaian keberlanjutan perikanan, maka perlu untuk melihat bagaimana keberlanjutan perikanan tangkap skala kecil dari beberapa dimensi keberlanjutan yaitu ekologi, ekonomi, sosial, teknologi dan hukum-kelembagaan. Beberapa aspek keberlanjutan ini dapat dijadikan salah satu dasar untuk melihat status keberlanjutan suatu kawasan perairan perikanan sehingga dapat dijadikan sebagai rujukan dalam menyusun kebijakan pengelolaan sumberdaya perikanan atau keberlanjutan perikanan tangkap di kawasan tersebut. Oleh karena itu penelitian ini perlu dan sangat penting dilakukan mengingat keberlanjutan perikanan skala kecil tersebut dapat mencerminkan arah perkembangan perikanan nasional di masa yang akan datang. Tujuan dari penelitian ini adalah untuk menggambarkan status keberlanjutan perikanan tangkap skala kecil di Kabupaten Tegal, Jawa Tengah dan memberikan rekomendasi kebijakan pengelolaan perikanan tangkap skala kecil di Kabupaten Tegal, Jawa Tengah

\section{METODE}

\section{Lokasi dan Waktu Penelitian}

Penelitian ini dilakukan terhadap perikanan tangkap skala kecil yang beroperasi di perairan Kabupaten Tegal, Jawa Tengah. Peta lokasi penelitian disajikan pada Gambar 1. Penelitian ini dimulai pada bulan Nopember 2005 sampai dengan bulan Maret 2006.

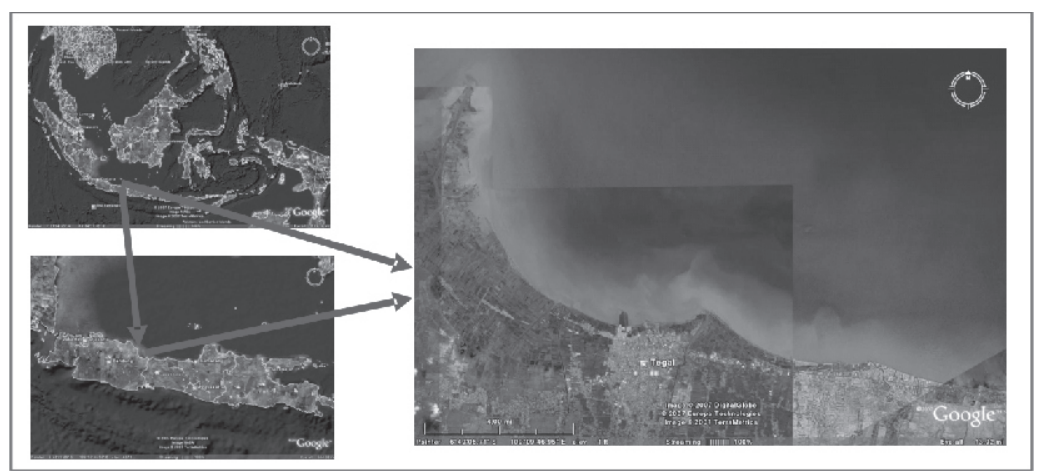

(Sumber/Source: Google earth, 24 Juli 2007)

Gambar 1. Lokasi Penelitian di Kabupaten Tegal, Jawa Tengah

Figure 1. Research Location in Tegal District, Central Java 


\section{Kerangka Pendekatan}

Salah satu isu pembangunan perikanan yang dihadapi oleh negara-negara berkembang termasuk Indonesia adalah bagaimana menyeimbangkan antara tujuan sosial, ekonomi, teknologi, hukumkelembagaan dengan keberlangsungan sumberdaya perikanan (ekologi). Peningkatan jumlah penduduk yang memanfaatkan sumberdaya perikanan sebagai sumber mata pencaharian untuk pemenuhan kebutuhan ekonomi merupakan faktor utama yang menyebabkan tingginya tekanan pemanfaatan sumberdaya perikanan (Charles, 2001). Menurut Kusumastanto (2000), fenomena ini memerlukan suatu rumusan perencanaan pengelolaan sumberdaya perikanan secara komprehensif dan memenuhi kriteria pembangunan terpadu berkelanjutan yaitu secara ekonomi harus efisien dan optimal, secara sosial budaya berkeadilan dan dapat diterima, dan secara ekologis tidak melampaui daya dukung lingkungan (environmentally friendly). Pemanfaatan dan pengelolaan sumberdaya perikanan semestinya dilakukan untuk mencapai tujuan pembangunan perikanan berkelanjutan, yaitu pertumbuhan ekonomi, pemerataan kesejahteraan dan perbaikan kualitas lingkungan. Perencanaan pengelolaan dilakukan dengan mengakomodasi seluruh kepentingan para stakeholders, menghimpun informasi yang lengkap, akurat dan terbaru, serta dilakukan dengan prosedur dan pendekatan yang secara ilmiah dapat dipertanggungjawabkan.

Pada Gambar 2, penelitian ini menggambarkan isu dan permasalahan perikanan tangkap skala kecil di Kabupaten Tegal dan diidentifikasi faktor-faktor yang mempengaruhi aspek keberlanjutan. Faktorfaktor yang mempengaruhi aspek keberlanjutan ini dikaji dengan alat ukur berupa indikator keberlanjutan ekologi, ekonomi, sosial, teknologi, hukumkelembagaan baik hasil dari beberapa sumber (FAO, rapfish, dII) maupun pra survei yang disesuaikan dengan kondisi spesifik perikanan tangkap skala kecil di Kabupaten Tegal. Hasil indikator tersebut kemudian diketahui status keberlanjutan perikanan tangkap skala kecil di Kabupaten Tegal. Status keberlanjutan ini digunakan untuk mengkaji keberlanjutan perikanan tangkap skala kecil di Kabupaten Tegal. Hasil evaluasi status keberlanjutan kemudian dianalisis agar dapat digunakan menjadi rekomendasi dalam menyusun kebijakan pengelolaan perikanan yang berkelanjutan di wilayah penelitian pada khususnya dan wilayah Indonesia secara umum pada keberlanjutan perikanan tangkap skala kecil.

\section{Pengumpulan Data, Jenis dan Sumber Data}

Data yang dikumpulkan yaitu data primer dan data sekunder. Data primer dikumpulkan dengan cara wawancara dengan menggunakan instrumen terstruktur dan pengamatan langsung semi partisipatif (partisipatory observation) di lokasi terpilih. Data tersebut meliputi data aspek ekonomi, sosial, etika, hukum-kelembagaan serta teknis penangkapan dari armada penangkapan. Sebagian data bio-ekologis dapat digali dari responden dan studi literatur. Sedangkan data sekunder adalah data yang tidak dapat diperoleh dari data primer sehingga perlu studi literatur, wawancara dengan pengelola perikanan maupun dengan observasi. Data tersebut dapat diperoleh dari dinas, lembaga atau instansi terkait dalam pengelolaan perikanan tangkap seperti Departemen Kelautan dan Perikanan, institusi penelitian perikanan, universitas, Dinas Perikanan dan Kelautan Tingkat I dan Tingkat II, organisasi nelayan, koperasi, Badan Pusat Statistik (BPS, 2003 dan BPS, 2004) dan daerah (BPS Kabupaten Tegal, 2003 dan BPS Kabupaten Tegal, 2004) serta instansi lain yang terkait dengan kajian ini baik instansi pemerintah dan non pemerintah.

Untuk memenuhi kriteria data yang relevan dengan pendekatan aplikasi Rapfish, 


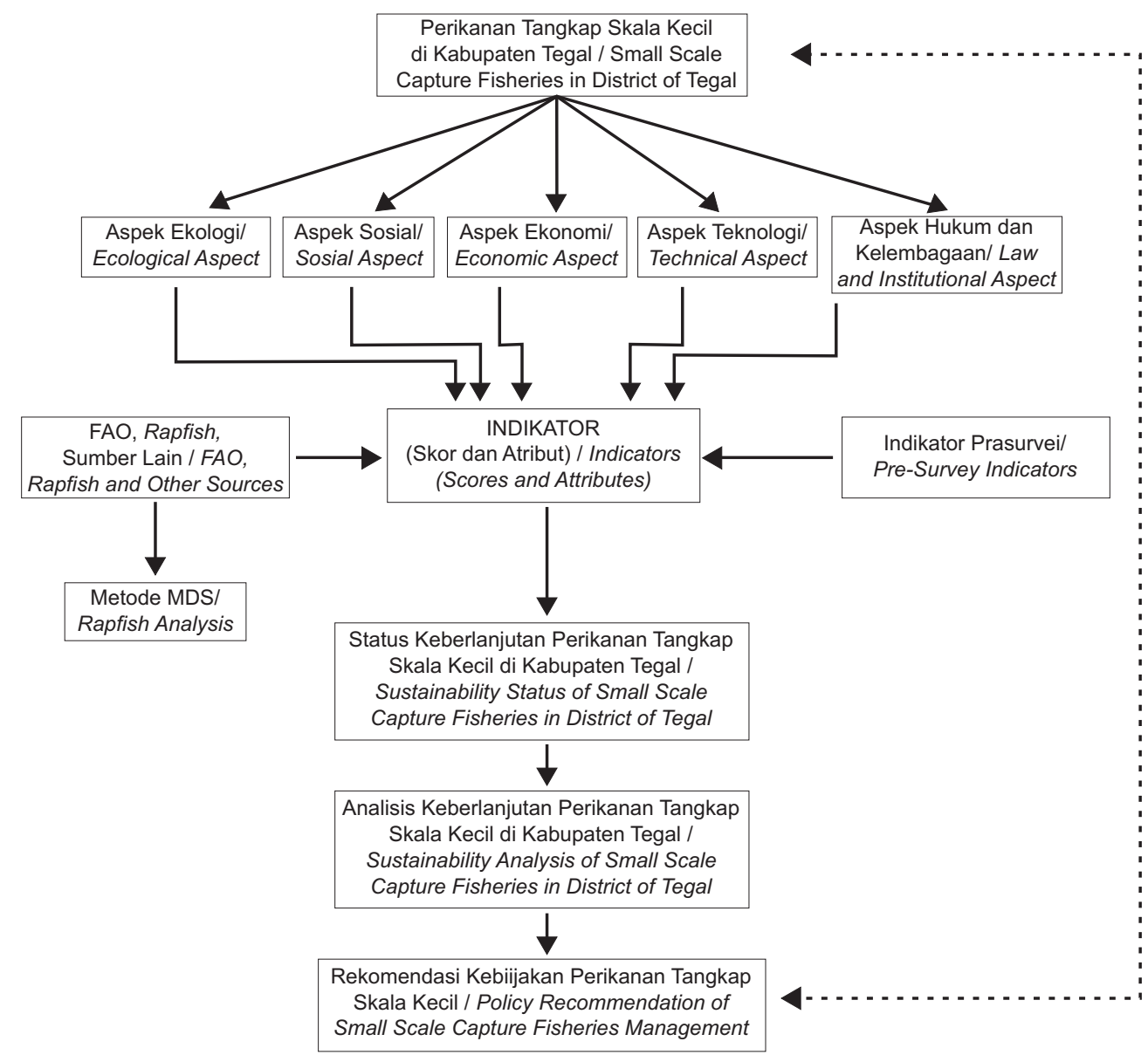

\section{Gambar 2. Kerangka Pendekatan Studi Analisis Status Keberlanjutan Perikanan Tangkap Skala Kecil di Kabupaten Tegal, Jawa Tengah}

Figure 2. Framework Approach of The Analytical Study on the Status of Small-Scale Fishery Sustainability in Tegal District, Central Java

maka kegiatan pengumpulan data dilakukan sebagai berikut:

1) Pengumpulan laporan terkait atau publikasi ilmiah

2) Pengumpulan data yang sama dari sumber berbeda (klarifikasi kemutakhiran data)

3) Verifikasi lapang untuk observasi langsung dan wawancara konfirmasi (dengan nelayan, pengolah, atau informan kunci lainnya) dalam rangka meningkatkan akurasi data.

4) Penyiapan kuesioner yang terkait langsung dengan atribut Rapfish.

\section{Metode Analisis Data}

Metode penelitian yang digunakan dalam penelitian ini mengacu pada teknik Rapfish (Rapid Appraissal for Fisheries) adalah teknik terbaru yang dikembangkan oleh University of British Columbia Canada, yang merupakan analisis untuk mengevaluasi sustainability dari perikanan secara multidisipliner. Rapfish didasarkan pada teknik ordinasi yaitu menempatkan sesuatu pada urutan atribut yang terukur dengan menggunakan Multi-Dimensional Scaling (MDS). Aspek dalam Rapfish menyangkut aspek keberlanjutan dari ekologi, ekonomi, 
teknologi, sosial dan etika. Setiap aspek memiliki atribut atau indikator yang terkait dengan sustainability sebagaimana yang disyaratkan oleh FAO (1995), FAO (1999a), FAO (1999b), FAO (2001) dan Pitcher et al. (1998). Dengan Rapfish, atribut-atribut tersebut diadaptasikan dari atribut yang telah dikembangkan oleh Pitchert et al. (2000) yang telah terbukti sejalan dengan indikator FAO Code of Conduct for Responsible Fisheries. Prosedur dari Rapfish menurut Alder, et.al. (2000) yang diacu dalam Hermawan (2006) mengikuti struktur pada Gambar 3.

Dalam analisis dengan pendekatan teknik Rapfish ini, akan digunakan metode Algoritma ALSCAL yang merupakan metode aplikatif yang sudah tersedia dalam software statistika (SPSS). Secara detail prosedur analisis dengan teknik Rapfish ini akan melalui beberapa tahapan sebagai berikut:

1. Analisis terhadap data perikanan lokasi studi melalui data statistik.

2. Analisis data pengamatan lapangan dan studi literatur.

3. Melakukan skoring aspek keberlanjutan perikanan.

4. Melakukan analisis Multi-Dimensional Scaling (MDS) dengan template excel untuk menentukan ordinasi dan nilai stress melalui ALSCALAlgoritma

5. Melakukan rotasi untuk menentukan posisi perikanan pada ordinasi bad dan good.

6. Melakukan sensitivity analysis (Leverage analysis) dan Monte Carlo analysis untuk memperhitungkan aspek ketidakpastian.

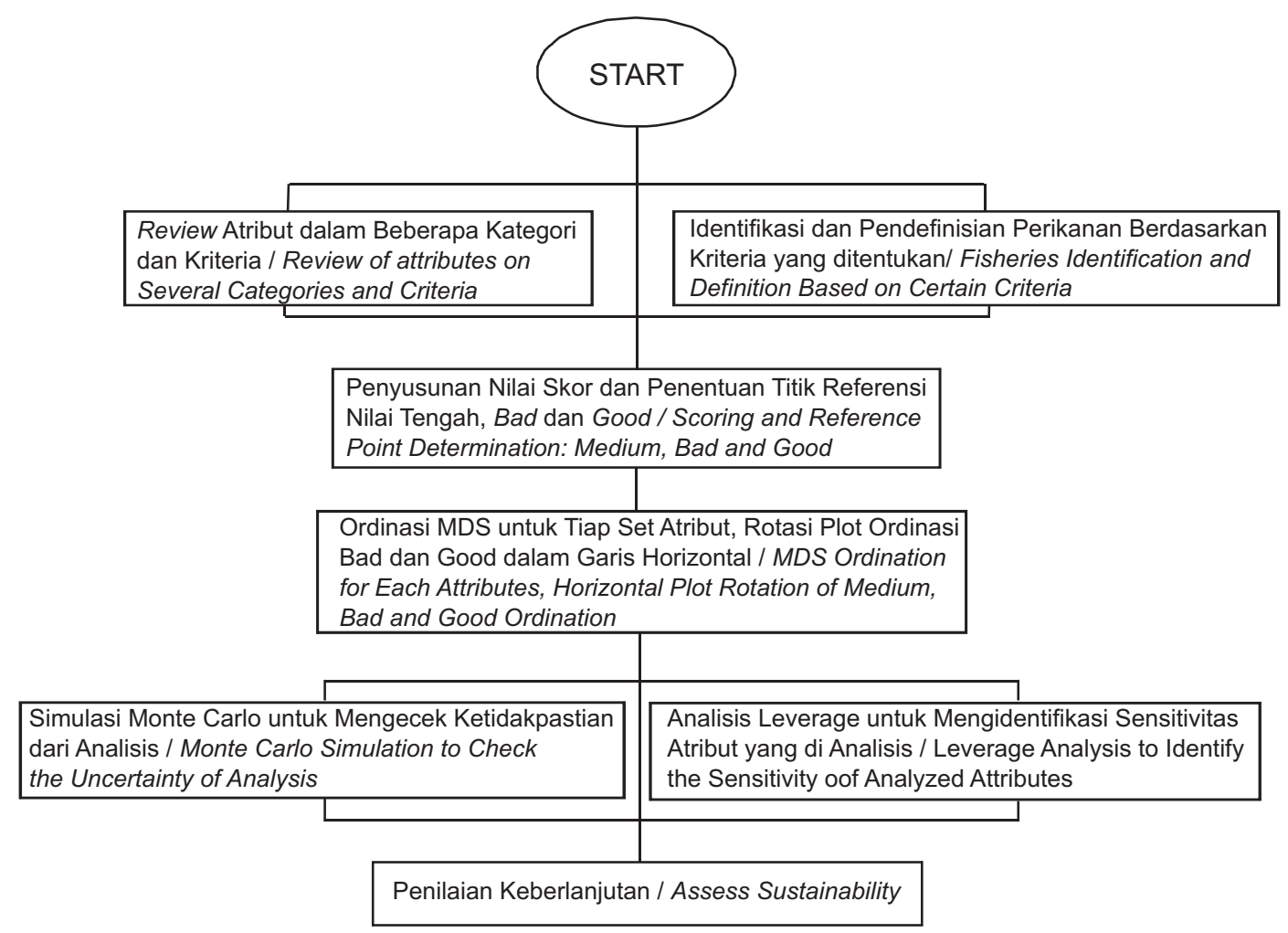

Sumber/source : Alder, et.al. (2000) yang diacu dalam Hermawan (2006)

Gambar 3. Proses/Tahapan Aplikasi Rapfish pada Perikanan Tangkap

Figure 3. Rapfish Application Process for Fisheries' Sustainability 


\section{Model yang Digunakan}

Rapfish merupakan salah satu metode dalam menganalisis keberlanjutan perikanan dan termasuk baru dalam penerapan multidimentional scaling di bidang perikanan. Metode Rapfish pada dasarnya menggunakan pendekatan Multi Dimentional Scaling (MDS). Seluruh atribut yang diperoleh dari hasil penelitian ini dianalisis secara multidimensi. Analisis multidimensi ini untuk menentukan titik-titik dalam Rapfish yang dikaji relatif terhadap dua titik yang menjadi acuan. Titik yang menjadi acuan tersebut adalah baik (good) dan buruk (bad), dimana ada titik ekstrem good dan titik ekstrem bad.

Nilai indeks keberlanjutan perikanan skala kecil ini pada metode Rapfish diketahui mempunyai nilai bad (buruk) sampai good (baik) dalam selang 0-100. Untuk memudahkan penentuan status keberlanjutan perikanan tangkap skala kecil baik di Kabupaten Tegal maka selang dari bad (0) sampai good (100) tersebut dibagi menjadi beberapa kategori atau status, yaitu dengan membagi empat selang dari 0-100 tersebut. Selang indeks keberlanjutan tersebut yaitu selang 0-25 dalam status buruk, selang 26-50 dalam status kurang, selang 51-75 dalam status cukup dan selang 76-100 dalam status baik (Susilo, 2003). Pembagian selang yang menggambarkan status indeks keberlanjutan ekologi tersebut dapat dilihat pada Tabel 1. berikut :

$d_{1,2}=\sqrt{\left(x_{1}-x_{2}\right)^{2}+\left(y_{1}-y_{2}\right)^{2}+\ldots \ldots}$

Jarak Euclidean multi dimensi antara dua titik tersebut (d12) kemudian di dalam MDS diproyeksikan ke dalam jarak Euclidean dua dimensi (D12) berdasarkan rumus regresi pada persamaan (2) berikut :

$$
d_{12}=a+b D_{12}+e \text {; e adalah error. }
$$

Proses regresi tersebut di dalam Rapfish menggunakan algoritma ALSCAL yang pada prinsipnya membuat iterasi proses regresi tersebut di atas sedemikian sehingga didapatkan nilai e yang terkecil. Algoritma ALSCAL yang digunakan pada Rapfish menurut Kavanagh (2001) juga berusaha memaksa agar intercept pada persamaan tersebut sama dengan nol $(a=0)$ sehingga persamaan (2) di atas menjadi persamaan (3) berikut:

$$
d_{12}=b D_{12}+e .
$$

Iterasi berhenti jika stress lebih kecil dari 0,25 (Fauzi dan Anna, 2005). Stress ini dapat dirumuskan dalam persamaan (4) yaitu :

Stress $=\sqrt{\frac{1}{m} \sum_{k=1}^{m}\left[\frac{\sum_{i} \sum_{j}\left(D_{i j k}-d_{i j k}\right)^{2}}{\sum_{i} \sum_{j} d_{i j k}^{2}}\right]}$

Tabel 1. Selang Indeks dan Status Keberlanjutan Perikanan Tangkap Skala Kecil Table 1. Interval of Index and Sustainability Status of Small Scale Fisheries

\begin{tabular}{ccc}
\hline No & $\begin{array}{l}\text { Selang Indeks Keberlanjutan/ } \\
\text { Interval of Sustainability Index }\end{array}$ & $\begin{array}{c}\text { Status Keberlanjutan I } \\
\text { Sustainability Status }\end{array}$ \\
\hline 1 & $0-25$ & Buruk / Bad \\
2 & $26-50$ & Kurang / Poor \\
3 & $51-75$ & Cukup / Adequate \\
4 & $76-100$ & Baik / Good \\
\hline
\end{tabular}

Sebagaimana diuraikan di dalam Fauzi dan Anna (2005), MDS pada Rapfish dilakukan dengan menghitung jarak terdekat dari Euclidean distance pada persamaan (3.1)
Kavanagh (2001) mengemukakan bahwa iterasi berhenti jika $S$-stress kurang dari 0,005 . Menurutnya $S$-stress $=($ stress $) 1 / 2$ sementara stress didefinisikan dalam 
persamaan (5)

Stress $=\frac{M S S e_{i j k}}{M S S d_{i j k}}$

Metode MDS merupakan salah satu metode ordinasi pada ruang (dimensi) yang diperkecil. Ordinasi suatu obyek pengamatan yang diukur dengan menggunakan banyak variabel sulit dilihat secara visual mengingat bahwa posisi obyek di dalam ruang berdimensi lebih dari 3 tidak mungkin digambarkan. Metode MDS mempunyai tahapan sebagai berikut:

(1) Standardisasi (normalisasi). Variabel yang mempunyai unit dan besaran yang berbeda harus distandarisasi terlebih dahulu agar dapat dianalisis.

(2) Pengukuran jarak multidimensi. Dalam penelitian ini pada prinsipnya terdapat tiga obyek alat tangkap yang menjadi topik kajian ini. Jarak antara ketiga alat tangkap tersebut terhadap titik pusat koordinat dapat dihitung.

(3) Analisis reduksi dimensi. Analisis ini juga dilakukan alogiritma ALSCALL dengan template excel dengan metode MDS dimana posisi obyek dalam ruang multidimensi di atas diplotkan kembali pada ruang dua dimensi.

(4) Pengukuran jarak dua dimensi. Dua obyek penelitian tersebut sekali lagi diukur jaraknya, tetapi sekarang di dalam dua dimensi.

(5) Pengukuran nilai stress. Stress merupakan "nilai simpangan baku" dari metode MDS. Makin kecil stress tentunya makin baik. Stress ini pada prinsipnya mengukur seberapa dekat nilai jarak dua dimensi dengan nilai jarak multi dimensi. Jika jarak antara dua nilai jarak ini dekat berarti simpangannya kecil dan berarti juga nilai stress-nya kecil. Nilai stress terbesar yang masih dapat diterima biasanya adalah $25 \%$. Menurut Fauzi dan Anna (2005) adalah jika nilai stress atau yang dilambangkan dengan $S$ semakin rendah menunjukkan goodness of fit, sementara nilai $S$ yang tinggi menunjukkan sebaliknya.

\section{HASIL DAN PEMBAHASAN}

Penentuan skala ekonomi pada kajian ini merupakan titik dasar dari penentuan skala usaha perikanan yang diteliti, dimana beberapa kriteria pembatas perikanan tangkap skala kecil yang akan dipenuhi harus ditentukan terlebih dahulu. Penentuan kriteria dilakukan berdasarkan kriteria Charles (2001) dan hasil studi yang dilakukan di perairan pantai Kabupaten Tegal oleh Hermawan (2006). Kriteria tersebut diantaranya adalah (1) total investasi awal $=30$ juta rupiah, (2) kepemilikan aset sendiri (bukan perusahaan milik pengusaha besar), (3) wilayah penangkapan dalam zona IA, (4) lama trip penangkapan 1 hari (one day fishing), (5) teknologi paling tinggi dalam operasi penangkapan hanya menggunakan motor tempel (10-25 PK), (6) panjang kapal yang digunakan 5-10 m.

Di samping kriteria tersebut di atas penentuan skala perikanan dalam kajian ini, juga mempertimbangkan kriteria yang dibuat oleh Smith (1979). Dari penentuan kriteria perikanan tangkap skala kecil di Kabupaten Tegal diperoleh armada perikanan yang menggunakan alat tangkap dan dijadikan sebagai analisis keberlanjutan. Analisis alat tangkap digunakan di Kabupaten Tegal tersebut adalah payang gemplo (payang jabur), bundes dan jaring rampus. Jenis ikan dominan yang tertangkap dengan menggunakan setiap alat tangkap tersebut adalah teri nasi, teri jawa, rebon, pepetek, tenggiri, tigawaja, leres/julung-julung, tembang, beloso, kembung, udang dan rajungan.

Hasil analisis kelima aspek dari dimensi keberlanjutan perikanan tangkap skala kecil di Kabupaten Tegal dapat dilihat pada Gambar 4 sampai dengan Gambar 8. Pada Gambar 4 sampai dengan Gambar 8, garis horizontal menunjukkan status keberlanjutan perikanan 
Tabel 2. Pengukuran Statistik dari Nilai Stress dan R-squared dengan MDS

Table 2. Statistic Measurement from Stress Value and R-squared with MDS

\begin{tabular}{clcc}
\hline No & \multicolumn{1}{c}{ Dimensi / Dimension } & Stress & Squared Correlation (\%) \\
\hline 1 & Ekologi / Ecology & 0.13 & 94 \\
2 & Ekonomi / Economic & 0.13 & 95 \\
3 & Sosial / Social & 0.15 & 89 \\
4 & Teknologi / Technology & 0.14 & 94 \\
5 & Hukum - Kelembagaan / Law - & 0.14 & 92 \\
& & & \\
\hline
\end{tabular}

sesuai dengan definisi selang indeks pada Tabel 1. Analisis ordinasi menggambarkan keberlanjutan perikanan tangkap Kabupaten Tegal yang mempunyai variasi dari masingmasing alat tangkap. Sedangkan untuk menggambarkan keabsahan rapfish secara statistik dengan pengukuran nilai strees dan $r$ squared (squared correlation) dari masingmasing dimensi. Persyaratan nilai stress secara statistik haruslah kurang dari 25 sedangkan $r$-squared mendekati 100\%. Sebagai contoh nilai stress yang diperoleh dari penelitian pada dimensi ekologi ini sebesar
$13,86 \%$. Hal ini menurut prosedur Multidimensional Scaling (MDS), nilai stress yang diperoleh kurang dari 25 persen $(S<25$ $\%)$ maka analisis Rapfish sudah memenuhi goodness of fit dan korelasi selang kepercayaan yang diberikan sudah cukup tinggi sebesar 94\%. Selanjutnya untuk pengukuran statistik dari masing-masing dimensi dapat dilihat pada Tabel 2 .

\section{Dimensi Ekologi}

Gambar 4a menunjukkan ordinasi seluruh alat tangkap pada dimensi ekologi.

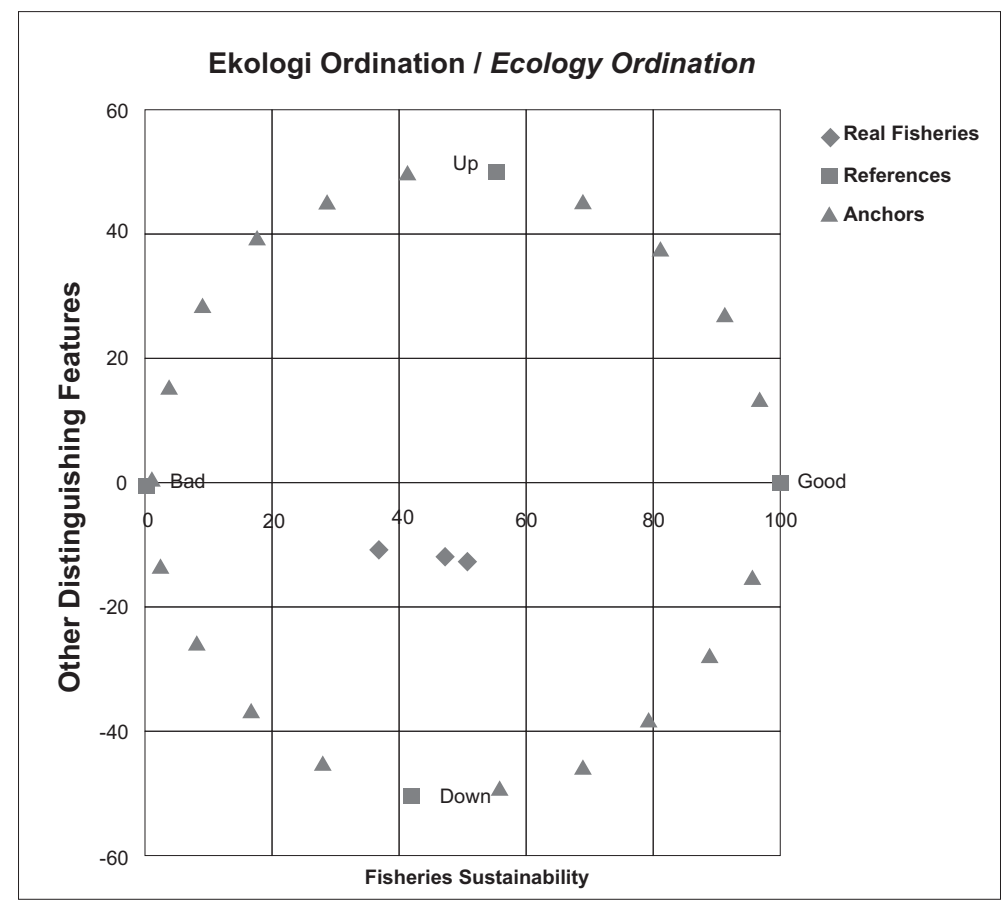

Gambar 4a. Ordinasi pada Dimensi Ekologi

Figure 4a. Ordination for Ecological Aspect 
Ordinasi Rapfish ini menggambarkan posisi keberlanjutan setiap alat tangkap berdasarkan indeks keberlanjutan perikanan tangkap skala kecil di perairan Pantai Kabupaten Tegal. Ordinansi keberlanjutan ekologi ketiga alat tangkap mempunyai nilai yang sama yaitu 27,87 (pada gambar terlihat berhimpit). Dapat dikatakan bahwa ketiga alat tangkap yang beroperasi di perairan Kabupaten Tegal yaitu bundes, rampus dan payang gemplo jika dilihat dari dimensi ekologi mempunyai status kurang berkelanjutan (indeks keberlanjutan pada Tabel 1).

Analisis leverage ini pada dasarnya untuk melihat bagaimana pengaruhnya terhadap skor keberlanjutan ekologi apabila satu atribut dikeluarkan dari analisis sehingga bisa dilihat tingkat sensitivitas skor keberlanjutan ekologi akibat dikeluarkannya satu atribut tersebut. Pada Gambar 4b, memperlihatkan bahwa atribut discard and by cacth (persentasi ikan yang dibuang) dan perubahan ukuran ikan yang tertangkap dalam 10 tahun terakhir merupakan atribut yang paling sensitif dalam keberlanjutan perikanan skala kecil di lokasi penelitian. Kondisi sensitivitas yang demikian menggambarkan bahwa perlu ada respons atau kebijakan yang berbasiskan ekologi untuk merespons terjadinya perubahan penurunan ukuran ikan yang tertangkap dalam kurun waktu 10 tahun terakhir. Hal ini sangat mendasar mengingat penurunan ukuran ikan merupakan salah satu indikasi penting bahwa telah terjadi penurunan stok ikan. Apabila hal ini dibiarkan maka kerusakan sumberdaya tidak akan dapat dicegah karena bisa saja bahwa ikan-ikan yang tertangkap adalah ikan-ikan yang belum dewasa dan belum sempat memijah sehingga proses penambahan stok melalui pembiakan (recruitment) terhenti. Di sisi lain proses pertumbuhan (growth) yang merupakan bagian dari recruitment juga terhenti, sehingga pada ahirnya akan mengarah pada penurunan

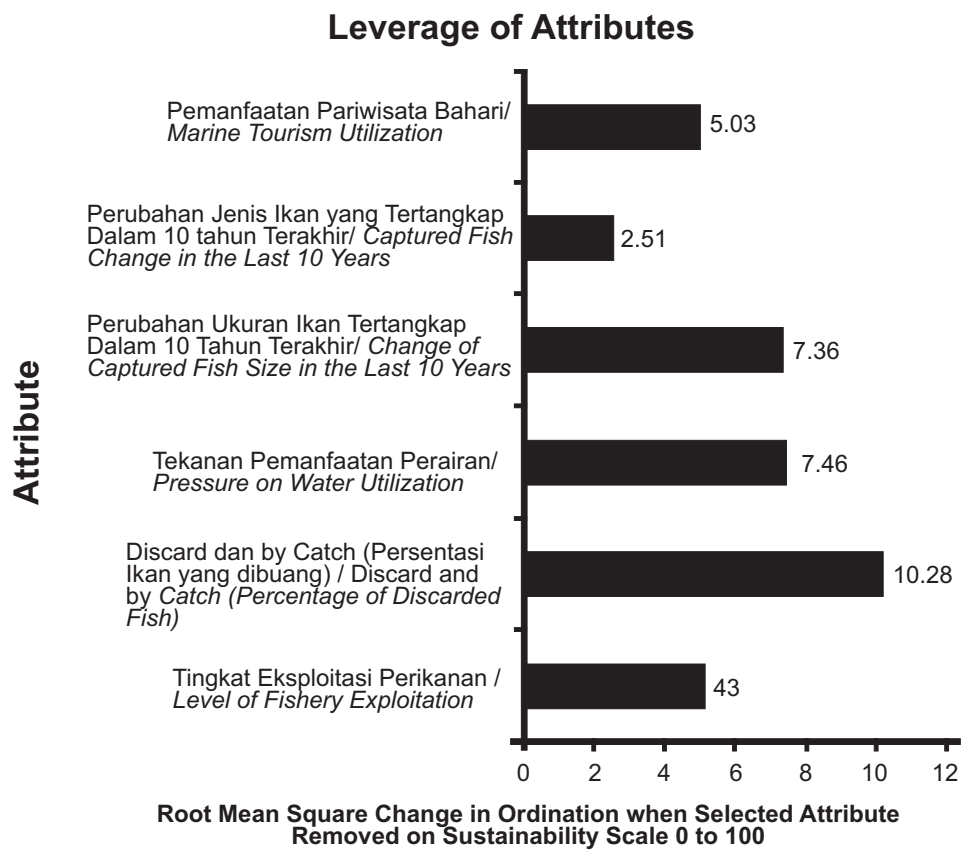

\section{Gambar 4b. Sensitivitas Atribut pada Dimensi Ekologi}

Figure 4b. Sensitivity of Atribute for Ecological Aspect 
stok secara keseluruhan (stock depletion) tidak dapat dihindari.

Dengan mencermati atribut yang paling mempengaruhi penentuan indeks dari dimensi ekologi yaitu discard and by catch dan perubahan ukuran ikan yang tertangkap seperti diuraikan di atas maka alternatif kebijakan juga harus mengakomodir status keberlanjutan dan faktor yang paling berpengaruh dalam keberlanjutan perikanan tangkap skala kecil di lokasi penelitian. Kebijakan yang terkait dengan atribut tersebut adalah peningkatan selektivitas alat tangkap yang digunakan dan ini harus mendapat perhatian dari pembuat kebijakan di Kabupaten Tegal di mana alat tangkap yang dioperasikan seperti bundes merupakan alat tangkap yang tidak selektif karena dapat menangkap ikan berbagai ukuran baik habitat dasar maupun permukaan. Di sisi lain beroperasinya jaring arad yang datang dari wilayah lain semakin memperburuk keadaan sumberdaya, karena sifat pengoperasian jaring arad yang menggaruk dasar perairan, juga tidak mempertimbangkan selektivitas ukuran dan jenis ikan yang hidup di habitat dasar perairan.
Pertimbangan ekologi dalam perikanan tangkap merupakan keharusan mengingat sudah sangat banyak contoh kerusakan sumberdaya akibat pengabaian terhadap aspek ekologi misalnya praktek penangkapan dengan cara-cara yang merusak.

\section{Dimensi Ekonomi}

Penggunaan alat tangkap yang selektif di samping bermanfaat bagi pengelolaan sumberdaya perikanan, juga bermanfaat secara ekonomi karena dengan menggunakan alat tangkap yang selektif diharapkan akan diperoleh ukuran ikan sesuai dengan kebutuhan pasar dan mengurangi risiko ikan tidak laku di pasar. Dengan demikian ikan yang berhasil ditangkap juga merupakan ikan yang bernilai lebih tinggi walaupun jumlahnya lebih sedikit dibandingkan dengan tidak dilakukan upaya peningkatan selektivitas alat tangkap yang banyak menghasilkan ikan dengan kualitas rendah.

Hasil ordinasi Rapfish pada dimensi ekonomi untuk seluruh alat tangkap yang dianalisis yaitu jaring rampus, bundes, dan payang gemplo dapat dilihat pada gambar $5 a$.

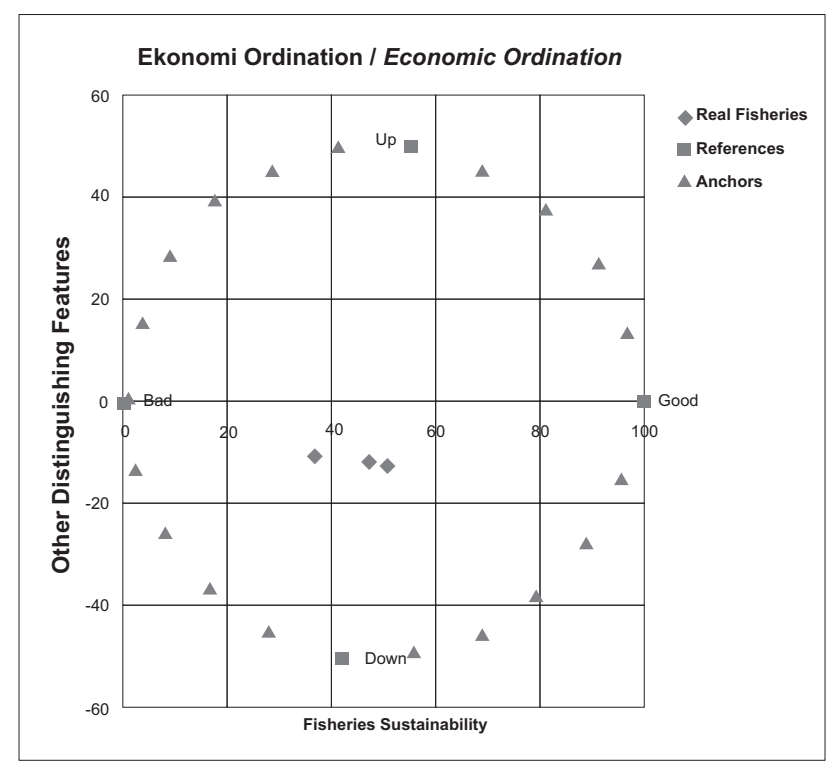

Gambar 5a. Ordinasi pada Dimensi Ekonomi

Figure 5a. Ordination for Economy Aspect 
Pada Gambar 5a sangat jelas digambarkan posisi status perikanan tangkap skala kecil di Kabupaten Tegal dilihat dari dimensi ekonomi. Ordinansi keberlanjutan ekonomi ketiga alat tangkap mempunyai indeks masing-masing yaitu jaring rampus sebesar 50,57 (cukup berkelanjutan), bundes sebesar 47,19 (kurang berkelanjutan), dan payang gemplo sebesar 36,66 (kurang berkelanjutan). Pada dimensi ekonomi memperlihatkan bahwa atribut sifat kepemilikan sarana penangkapan, tingkat subsidi, dan besarnya pemasaran perikanan merupakan atribut yang dominan mempengaruhi skor keberlanjutan perikanan skala kecil yang dikaji.
Pada Gambar 5b menunjukkan beberapa atribut sensitif. Sifat kepemilikan sarana penangkapan yang dikuasai bukan oleh masyarakat lokal akan terjadi peningkatan eksploitasi sumberdaya karena pemilik modal dari luar wilayah akan mempunyai kecenderungan untuk mengeksploitasi sumberdaya perikanan sebesar-besarnya dan secepat-cepatnya dan jika sudah tidak menguntungkan para pemilik modal dari luar ini akan memindahkan modalnya ke wilayah lain yang lebih menguntungkan. Besarnya subsidi yang diberikan pada sektor perikanan akan menyebabkan semakin besarnya tingkat

\section{Leverage of Attributes}

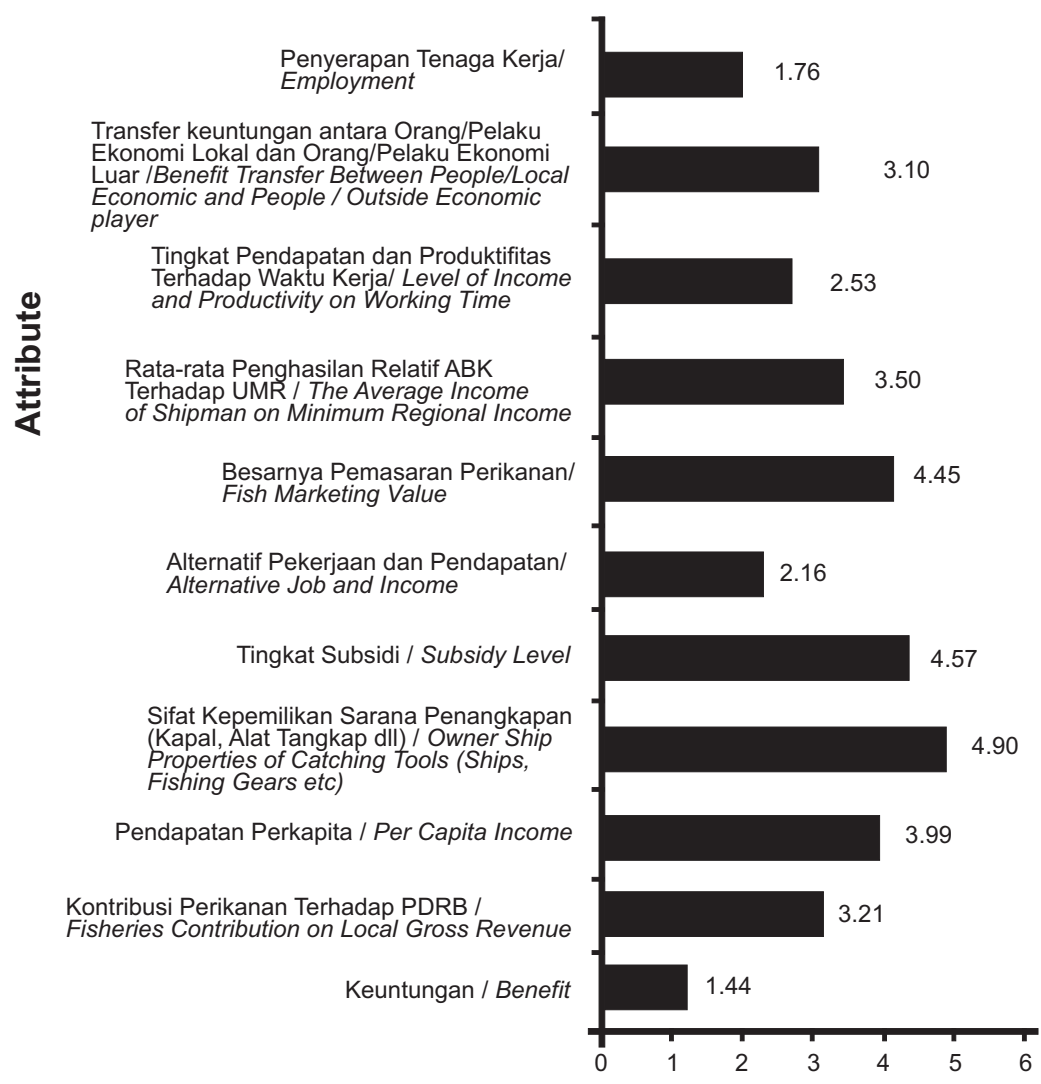

Root Mean Square Change in Ordination when Selected Attribute Removed on Sustainability Scale 0 to 100

Gambar 5b. Ordinasi dan Sensitivitas Atribut Pada Dimensi Ekonomi Figure 5b. Ordination and Sensitivity Atribute For Economy Aspect 
eksploitasi sumberdaya perikanan namun jika subsidi tidak diberikan usaha perikanan yang dilakukan nelayan sulit untuk diteruskan. Hal ini tentu saja menjadi kondisi yang sangat dilematis. Pemberian subsidi ini menjadi dilema karena secara jangka pendek nelayan memperoleh keuntungan namun dalam jangka panjang para nelayan ini sudah tidak bisa melaut, karena ketika ada subsidi nelayan akan mengeksploitasi sumberdaya secara maksimal terlebih lagi apabila persepsi discount rate yang tinggi dari para stakeholders perikanan tangkap. Oleh karena itu jika subsidi ingin terus diberikan hendaklah bukan subsidi untuk eksploitasi perikanan di perairan yang sudah overfishing namun diarahkan ke laut lepas yang masih tinggi stok ikannya. Subsidi juga dapat diberikan dengan peningkatan nilai tambah dari produk perikanan sehingga para nelayan mempunyai nilai lebih dari penjualan produk perikanannya. Di sisi lain, jika tingkat subsidi diturunkan maka harus ada perbaikan struktur harga jual ikan hasil tangkapan nelayan yang dihitung secara rasional. Begitu juga dengan besarnya pemasaran, semakin luas wilayah pemasaran, semakin tinggi permintaan terhadap ikan serta akan semakin besar tekanan terhadap sumberdaya perikanan.

\section{Dimensi Sosial}

Hasil ordinasi Rapfish pada dimensi sosial untuk seluruh alat tangkap yang dianalisis yaitu jaring rampus, bundes, dan payang Gemplo dapat dilihat pada Gambar 6a. Pada Gambar 6a sangat jelas digambarkan posisi status perikanan tangkap skala kecil di Kabupaten Tegal dilihat dari dimensi sosial. Ordinansi keberlanjutan sosial ketiga alat tangkap mempunyai indeks keberlanjutan yang masing-masing sama sebesar 60,77 (pada gambar terlihat berhimpit) dan mempunyai status cukup berkelanjutan.

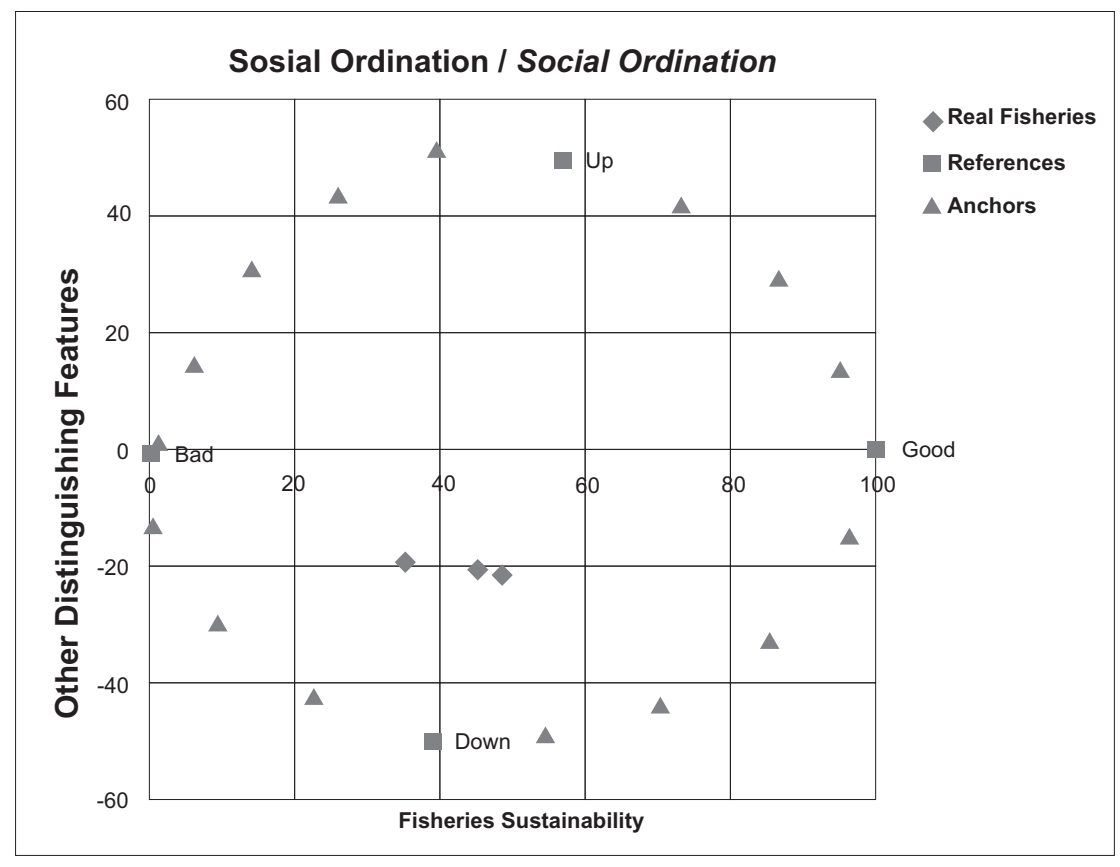

Gambar 6a. Ordinasi Pada Dimensi Sosial

Figure 6a. Ordination For Social Aspect 
Pada Gambar 6b menunjukkan hasil analisis sensitifitas atribut, ternyata atribut status dan frekuensi konflik, tingkat pendidikan dan partisipasi keluarga dalam pemanfaatan SDI, merupakan 3 atribut yang secara berurutan sangat berpengaruh terhadap nilai atau status keberlanjutan kegiatan perikanan tangkap skala kecil. Analisis leverage pada dimensi sosial atribut status dan frekuensi konflik merupakan atribut yang paling sensitif. Penyebab status dan frekuensi konflik ini adalah turunnya jumlah tangkapan dan berakibat langsung turunnya pendapatan sehingga para nelayan cenderung untuk memperluas wilayah penangkapan dan melakukan pelanggaran. Selain itu, penyebab konflik juga terjadi akibat ketidakjelasan kebijakan yang telah dibuat oleh instansi terkait. Status dan frekuensi konflik secara tidak langsung menyebabkan usaha perikanan mengalami kemunduran karena para nelayan akan mengalami kerugian materi dan psikis. Oleh karena itu, status dan frekuensi konflik perlu ditangani baik implementasi hukum maupun ketegasan aparat terhadap pelanggaran yang terjadi.

Tingkat pendidikan menjadi isu dalam pemanfaatan sumberdaya perikanan di Indonesia, karena tingkat pendidikan akan mempengaruhi pola pemanfaatan dan pengelolaan sumberdaya perikanan. Pencapaian pendidikan merupakan salah satu

\section{Leverage of Attributes}

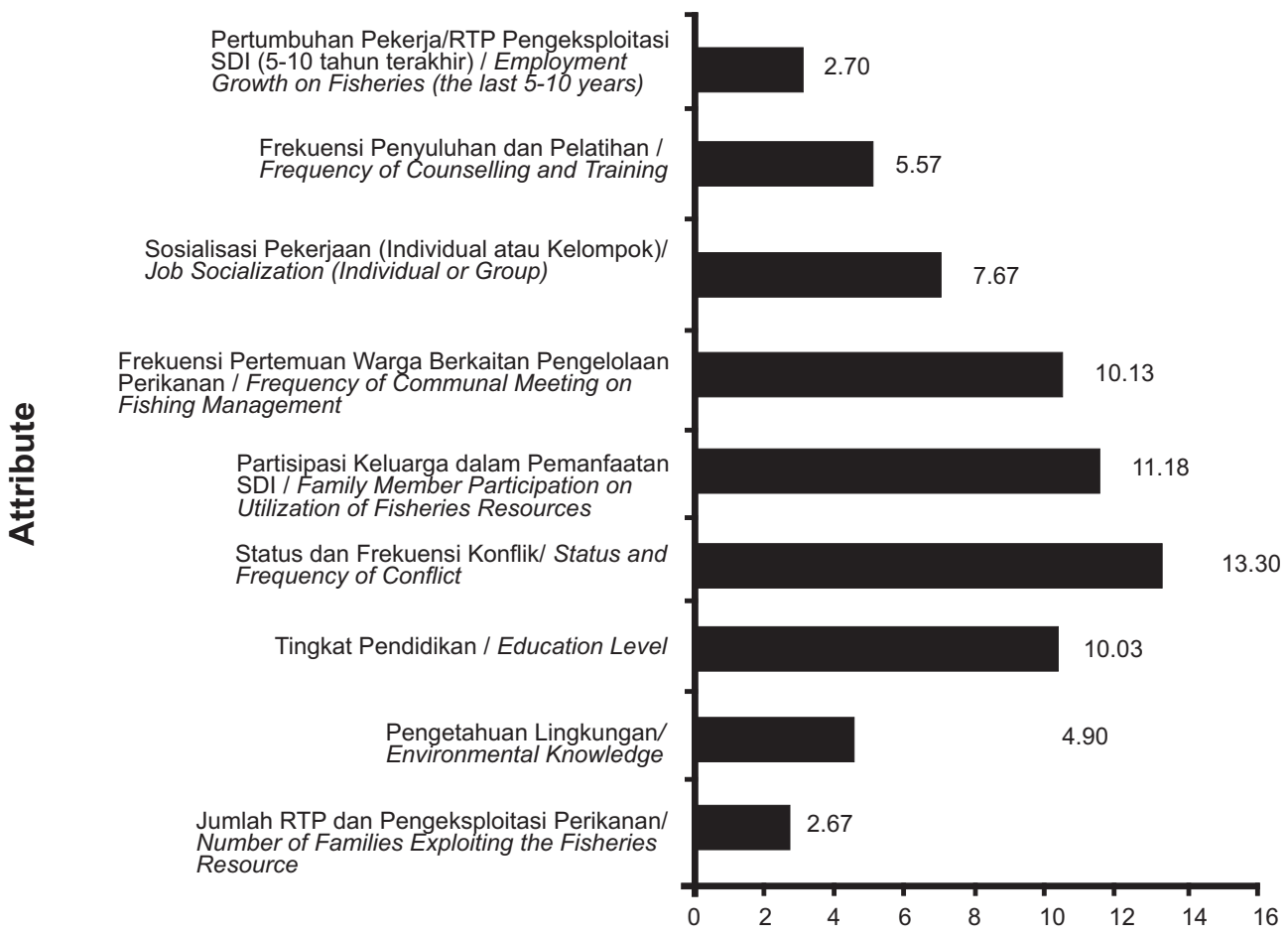

Root Mean Square Change in Ordination when Selected Attribute Removed on Sustainability Scale 0 to 100

\section{Gambar 6b. Sensitivitas Atribut Pada Dimensi Sosial} Figure 6b. Sensitivity of Atribute For Social Aspect 
ukuran untuk menilai kemajuan suatu masyarakat. Masyarakat yang berpendidikan tinggi akan lebih mudah menyerap informasiinformasi kemajuan peradaban, sehingga dapat meningkatkan kualitas penduduk daerah yang bersangkutan. Pendidikan juga mempunyai korelasi yang kuat dengan berbagai aspek sosial ekonomi. Berbagai penelitian menyimpulkan bahwa tingkat pendidikan mempunyai hubungan yang kuat dengan kualitas hidup dan kesejahteraan keluarga dan masyarakat. Karena itu pembangunan pendidikan sangat penting untuk mencetak generasi yang memiliki kemampuan dan kualitas yang unggul bagi kemajuan suatu bangsa. Partisipasi keluarga perlu ditingkatkan agar para nelayan tidak hanya mengandalkan sumber pendapatan keluarga dari tangkapan ikan namun dari bentuk lainnya, misalnya nilai tambah dari produk perikanan.

Kebijakan untuk dapat menjaga keberlanjutan usaha perikanan dari dimensi sosial diarahkan pada penurunan status dan frekuensi konflik dengan implementasi hukum yang jelas dan tegas. Peningkatan pendidikan para nelayan dibutuhkan agar dapat dengan cepat mengadopsi/menyerap informasi demi peningkatan kualitas hidup dan kesejahteraan mereka. Selain itu juga dibutuhkan peningkatan partisipasi keluarga agar para nelayan tidak hanya meningkatkan pendapatan dari peningkatan jumlah tangkapan dan tingkat ekploitasi tapi dapat meningkatkannya dari nilai tambah produk perikanan. Dengan demikian peningkatan kualitas pendidikan para nelayan akan sangat mendukung partisipasi nelayan dan keluarganya dalam meningkatkan wawasan dan kesadaran akan pentingnya menjaga keberlanjutan kegiatan perikanan tangkap melalui berbagai langkah yang lebih rasional.

\section{Dimensi Teknologi}

Indeks keberlanjutan perikanan tangkap pada dimensi teknologi di perairan Pantai Kabupaten Tegal ditunjukkan dengan jelas pada Gambar 7a. Indeks keberlanjutan untuk

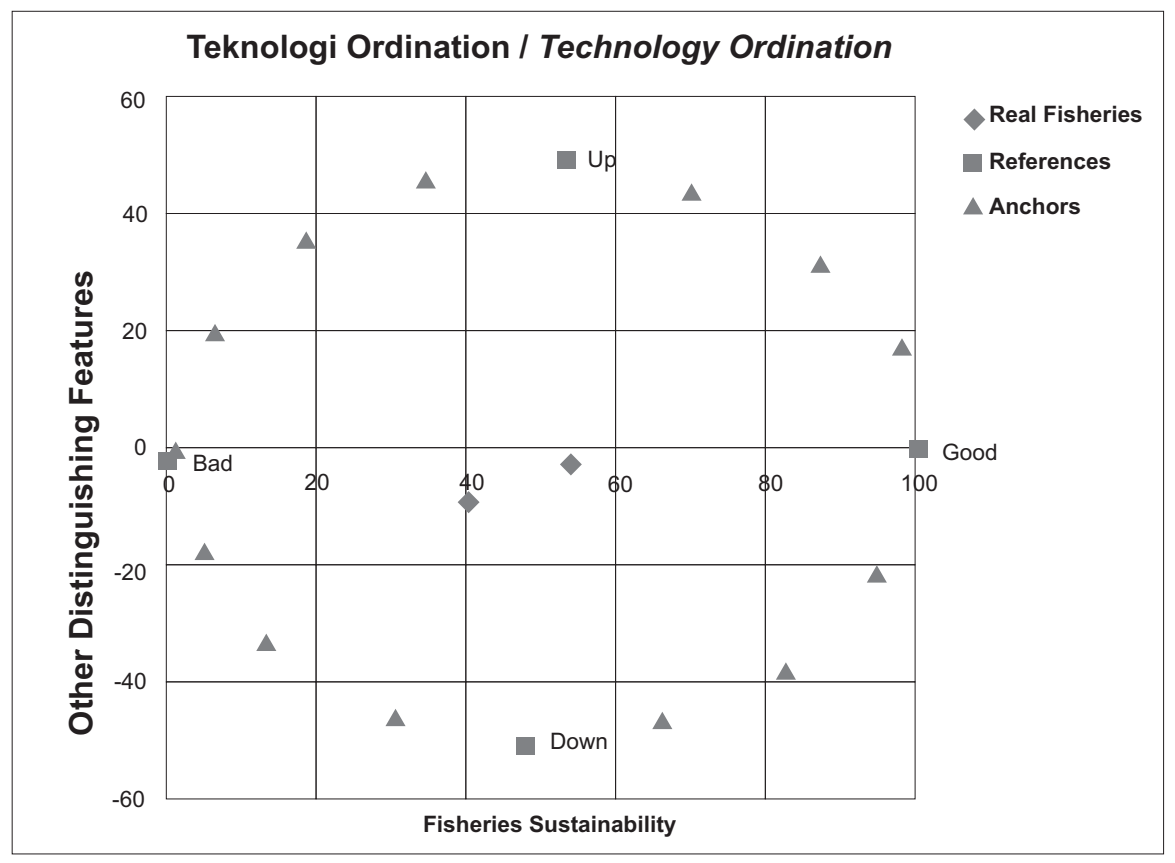

Gambar 7a. Ordinasi Pada Dimensi Teknologi

Figure 7a. Ordination For Technological Aspect 
perikanan tangkap di perairan Pantai Kabupaten Tegal yang menggunakan alat tangkap jaring rampus sebesar 53,49 sedangkan bundes dan payang gemplo masing-masing sebesar 39,98.

Pada Gambar 7b, analisis leverage pada dimensi teknologi memperlihatkan bahwa atribut penggunaan alat bantu penangkapan (FADS) dan selektifitas alat tangkap merupakan atribut yang paling dominan berpengaruh terhadap nilai atau status keberlanjutan kegiatan perikanan skala kecil dari dimensi teknologi. Hal ini dapat terjadi karena penggunaan alat bantu penangkapan (FADS) menjadi isu internasional yang dianggap dapat mengancam kelestarian sumberdaya ikan di perairan yang berkembang sejak konferensi internasional tentang FADS di Martinique, Prancis pada tahun 1999 dan berdasarkan pada ketentuan perikanan yang bertanggungjawab (CCRF) yang dikeluarkan FAO pada tahun 1995 (Hermawan, 2006). Oleh karena itu, kebijakan untuk dapat menjaga keberlanjutan kegiatan perikanan tangkap dari dimensi teknologi diarahkan pada pembatasan penggunaan alat bantu penangkapan (FADS) agar penurunan sumberdaya yang sangat drastis dapat dihindari mengingat FADS merupakan alat bantu yang diyakini sangat efektif dalam penangkapan ikan besar maupun kecil karena ikan-ikan terkonsentrasi pada FADS sehingga dapat dengan mudah tertangkap purse seine, payang, bagan atau pancing. Selain itu peningkatan selektifitas alat, karena dengan

\section{Leverage of Attributes}

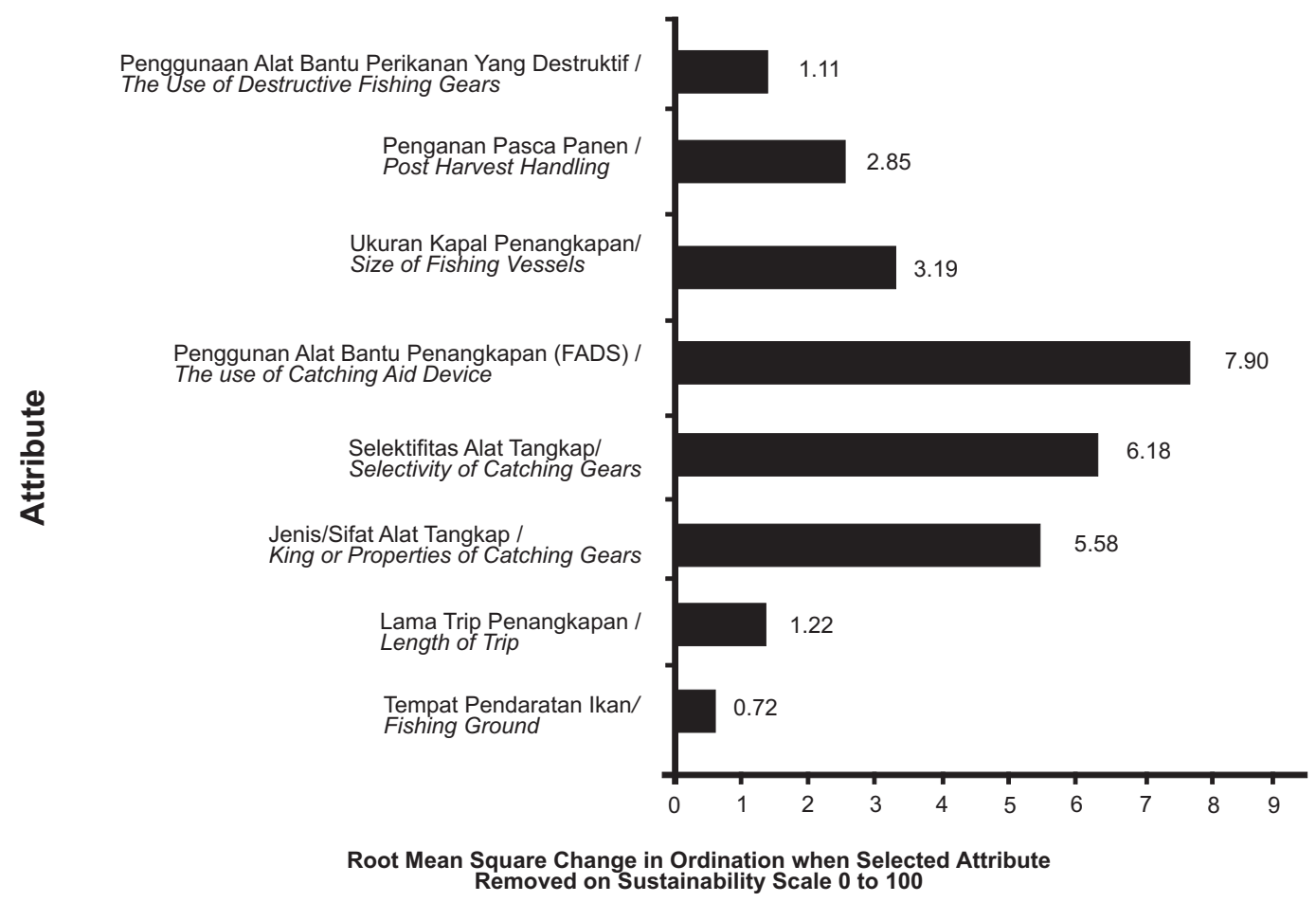

Gambar 7b. Sensitivitas Atribut Pada Dimensi Teknologi Figure 7b. Sensitivity of Atribute For Technological Aspect 
menggunakan alat tangkap yang selektif akan diperoleh ukuran ikan sesuai dengan kebutuhan pasar dan mengurangi resiko ikan tidak laku di pasar. Hal ini sesuai dengan rekomendasi yang dipaparkan pada dimensi ekologi dan dimensi ekonomi.

\section{Dimensi Hukum - Kelembagaan}

Gambar 8a berikut menunjukkan posisi status keberlanjutan perikanan tangkap perairan perairan Pantai Kabupaten Tegal pada dimensi hukum-kelembagaan. Pada Gambar 8a terlihat bahwa indeks keberlanjutan ketiga alat tangkap mempunyai nilai yang sama (pada gambar terlihat berhimpit) dengan nilai indeks masing-masing alat tangkap sebesar 32,85 atau mempunyai status kurang berkelanjutan.

Pada Gambar 8b menunjukkan hasil sensitivitas mengenai ketersediaan personil penegak hukum dan pengawas lokal menjadi salah satu faktor kunci agar pengelolaan sumberdaya perikanan dapat berjalan dari sisi dimensi hukum-kelembagaan. Selain itu, kebijakan untuk dapat menjaga keberlanjutan usaha perikanan dari dimensi hukumkelembagaan diarahkan untuk melibatkan para nelayan dalam penentuan kebijakan dan meningkatkan peran dari keberadaan tokoh masyarakat lokal. Demokrasi dalam penentuan kebijakan sangat diperlukan yaitu keterlibatan para nelayan sebagai salah satu stakeholder agar kebijakan-kebijakan yang telah dibuat tidak lagi menyimpang terhadap pengelolaan dan pemanfaatan sumberdaya perikanan. Efektifitas kebijakan yang dibuat oleh pemerintah bagaimanapun juga tergantung pada responsif dukungan dari masyarakat, dimana dukungan terhadap kebijakan muncul dari bawah yaitu nelayan itu sendiri (bottom up). Sehingga keberlanjutan perikanan tangkap bukan semuanya lagi pemerintah yang menentukan namun masyarakat nelayan ikut terlibat dengan mengetahui permasalahan yang sedang terjadi dan melakukan hubungan yang

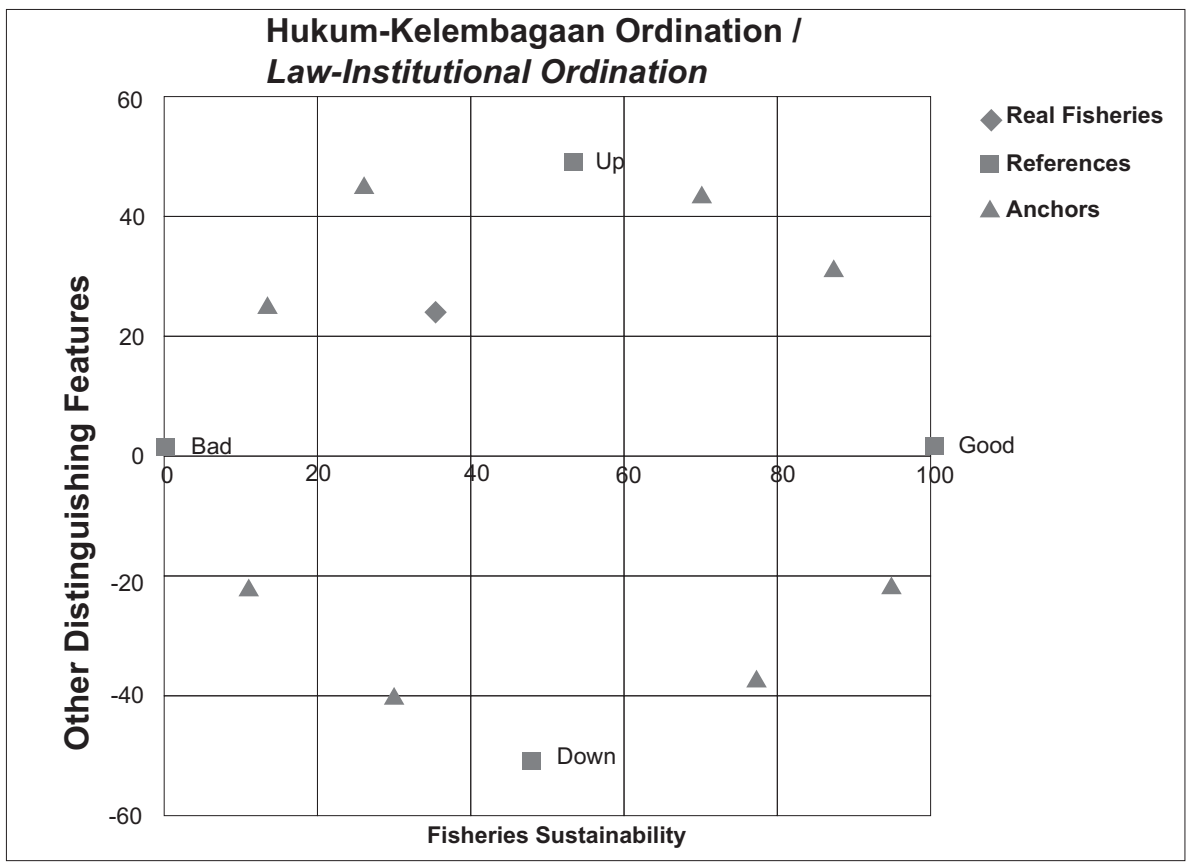

Gambar 8. Ordinasi dan Sensitivitas Atribut Pada Dimensi Hukum-kelembagaan Figure 8. Ordination and Sensitivity of Atribute For Legal-Institution Aspect 


\section{Leverage of Attributes}

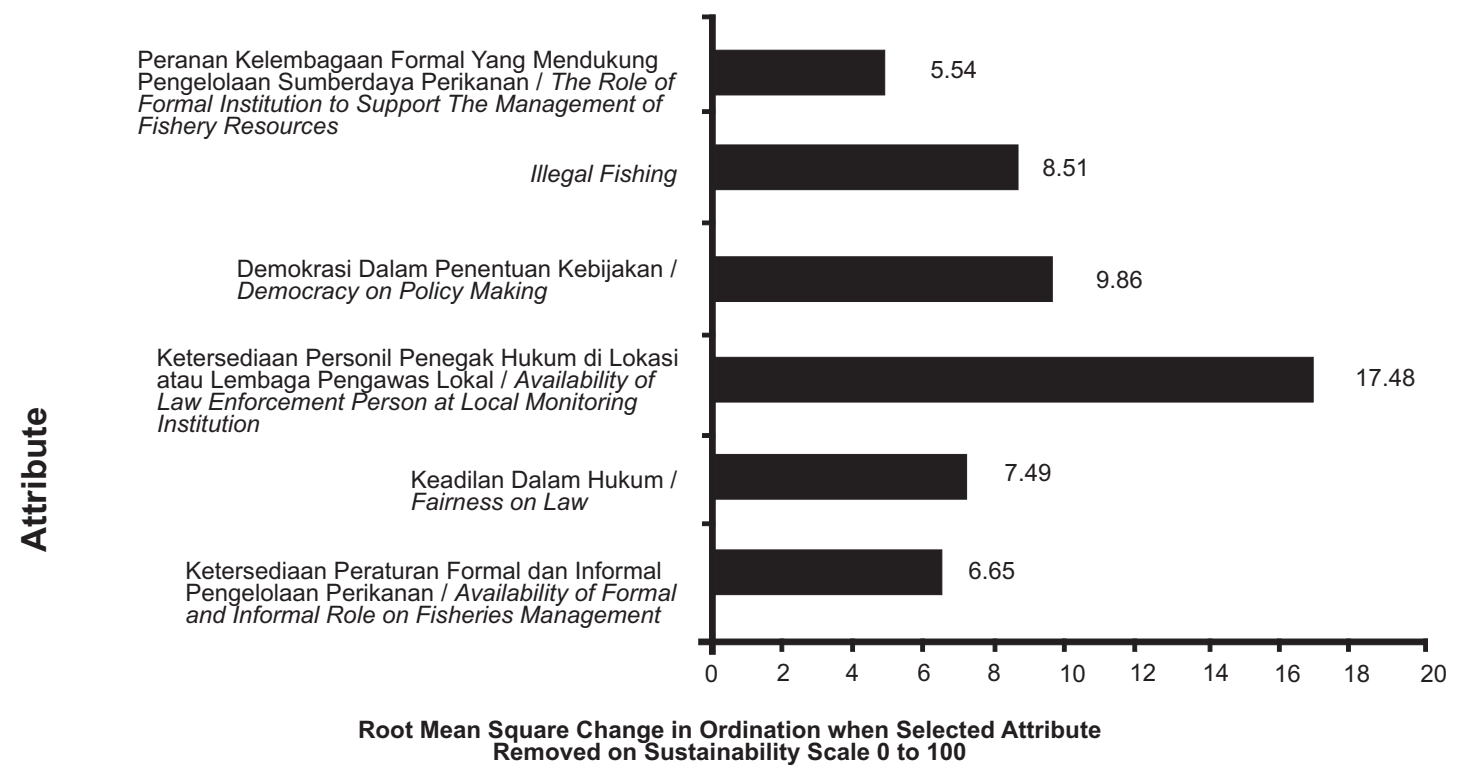

\section{Gambar 8b. Sensitivitas Atribut Pada Dimensi Hukum-kelembagaan Figure 8b. Sensitivity of Atribute For Legal-Institution Aspect}

komunikatif dengan masyarakat nelayan dan melibatkan peran dari tokoh masyarakat itu sendiri.

Contoh dari keberhasilan demokrasi penentuan kebijakan sebagai wadah keterlibatan nelayan dan peran tokoh masyarakat lokal adalah seperti Sasi di Maluku, Awig-awig di Lombok Barat, Panglima Laut di Aceh dan daerah lainnya.

Gambar 9 menampilkan diagram layang yang menggambarkan keterkaitan antar kelima dimensi sekaligus. Diagram layang menggambarkan skor dari $0 \%-100 \%$ dengan selang $25 \%$ yaitu buruk, kurang, cukup dan baik. Semakin indeks menuju keluar maka status keberlanjutan semakin baik demikian juga sebaliknya. Pada diagram layang terlihat bahwa secara keseluruhan indeks perikanan tangkap skala kecil di Kabupaten Tegal berada pada selang 25\% sampai dengan $75 \%$, yang menandakan status keberlanjutan ketiga alat tangkap yang beroperasi di Kabupaten Tegal berada pada status kurang dan cukup berkelanjutan. Pada dimensi ekologi, ekonomi dan hukumkelembagaan ketiga alat berada pada status kurang berkelanjutan yang artinya perlu dipikirkan untuk alternatif penggunaan alat tangkap atau peningkatan kapasitas/kualitas armada untuk dapat beroperasi keluar wilayah yang lebih jauh dimana daerah fishing groundnya masih banyak ikan. Pada dimensi teknologi hanya jaring rampus saja yang mempunyai status cukup berkelanjutan sedangkan kedua alat lainnya sudah mempunyai status kurang berkelanjutan. Pada dimensi teknologi ini jaring rampus juga sudah mendekati status kurang berkelanjutan yang jika dibiarkan akan menuju kurang berkelanjutan. Oleh karena itu, dapat dikatakan ketiga alat tangkap yang beroperasi ini pada dimensi teknologi sudah dalam kondisi yang mengkhawatirkan (kurang berkelanjutan). Pada dimensi sosial semua 


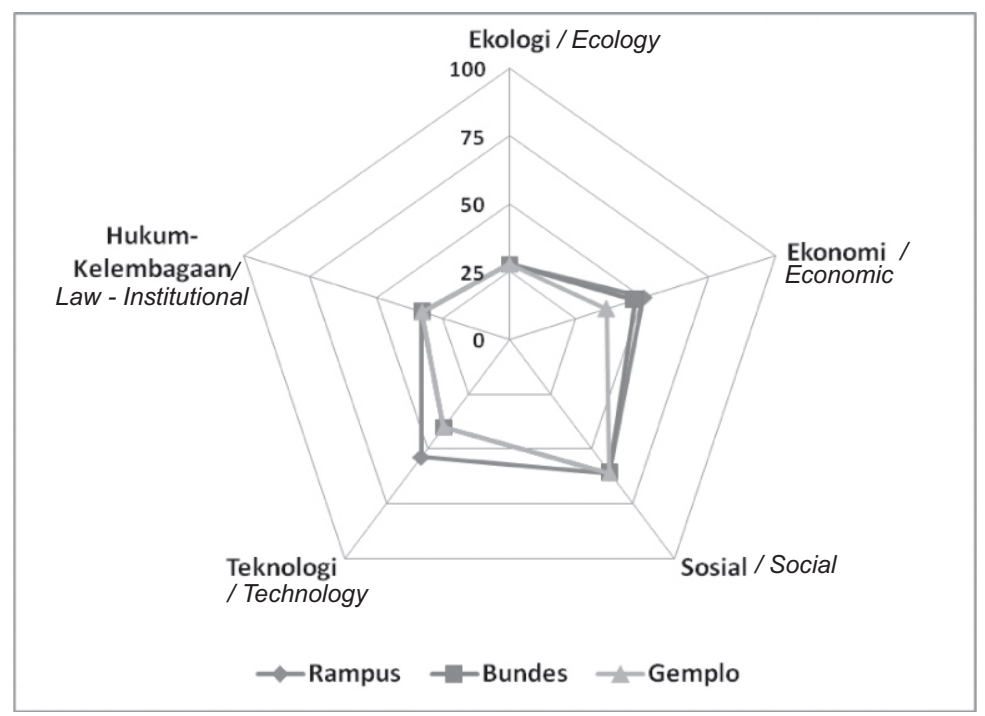

Gambar 9. Diagram layang analisis keberlanjutan perikanan tangkap skala kecil di Kab. Tegal

Figure 9. Radar diagram of small scale fisheries analysis in Kabupaten Tegal District

alat tangkap dalam status cukup berkelanjutan artinya perikanan tangkap skala kecil di Kabupaten Tegal mempunyai peran yang cukup penting bagi masyarakat nelayan.

Dalam tahapan Rapfish dijelaskan tentang mengatasi aspek ketidakpastian dengan simulasi Monte Carlo. Aspek ketidakpastian ini menurut Kavanagh (2001) dalam Fauzi dan Anna (2005) disebabkan oleh beberapa faktor antara lain dampak kesalahan skoring akibat minimnya informasi, dampak dari keragaman dalam skoring akibat perbedaan penilaian, kesalahan dalam data entry dan tingginya nilai stress yang diperoleh. Hasil simulasi Monte Carlo dengan 25 kali ulangan untuk dimensi ekologi, ekonomi, sosial, teknologi dan hukum-kelembagaan dapat dilihat masing-masing pada Gambar 10a, 10b, 10c, 10d dan 10e.

Hasil analisis simulasi Monte Carlo ini menunjukkan bahwa indeks keberlanjutan perikanan tangkap skala kecil di Kabupaten Tegal dengan menggunakan teknik Rapfish mempunyai hasil yang berkumpul di satu titik walaupun dengan pola yang menyebar pada masing-masing alat tangkap dan masingmasing dimensi. Artinya dengan 25 kali pengulangan dari beberapa faktor ketidakpastian di atas, hasil Rapfish yang diperoleh masih dalam jarak (distance) multidimensi sehingga dapat digunakan dalam penentuan status keberlanjutan dari setiap dimensi sesuai dengan kaidah MDS (multi dimentional scaling).

\section{KESIMPULAN DAN REKOMENDASI}

\section{Kesimpulan}

Kesimpulan yang dapat diberikan dari kajian ini antara lain :

1) Analisis rapfish dapat dijadikan analisis awal untuk memperoleh gambaran umum dan menyeluruh mengenai status keberlanjutan perikanan tangkap di lokasi penelitian mengingat sifatnya yang multidimensi sesuai dengan FAO-Code of Conduct for Responsible Fisheries. Dalam penelitian ini terbukti bahwa teknik Rapfish sangat bermanfaat untuk 


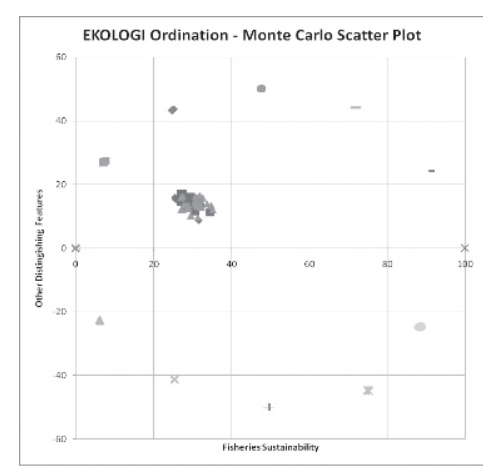

a

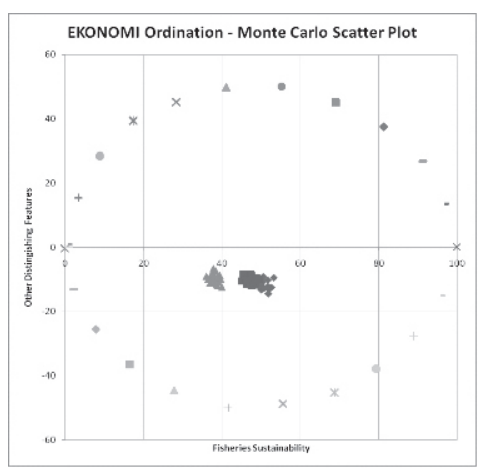

b

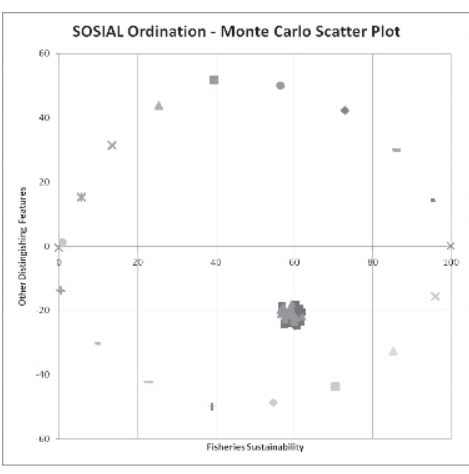

C

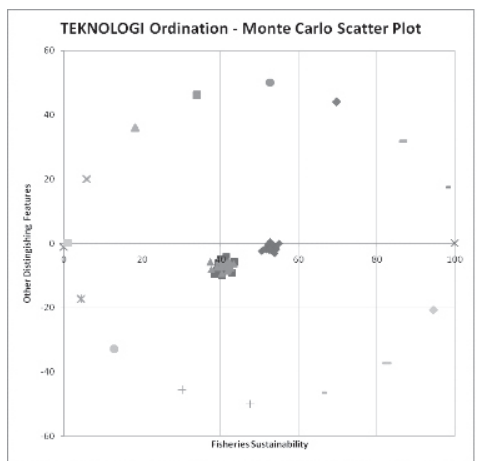

d

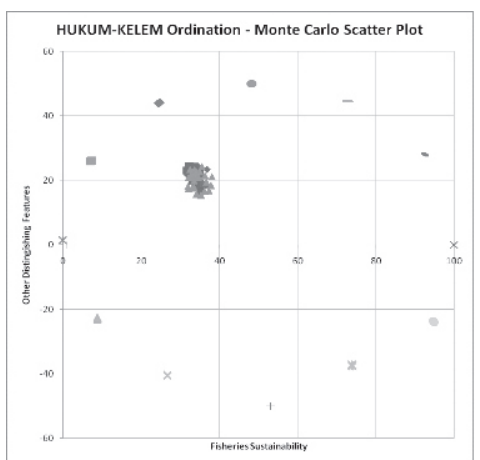

e

Gambar 10. Hasil simulasi Monte Carlo dari setiap dimensi keberlanjutan

Figure 10. Result of Monte Carlo simulation from each sustainability dimension

menentukan status keberlanjutan perikanan tangkap yang sangat komplek di lokasi penelitian. Seperti pisau bedah, teknik Rapfish mampu mengidentifikasi faktor-faktor penting yang mempengaruhi status keberlanjutan dari berbagai dimensi secara komprehensif. Analisis rapfish juga merupakan metode yang masih dapat dikembangkan di kemudian hari, seperti penambahan dimensi (aspek) lain selain kelima dimensi yang sudah ada dalam kajian ini atau penambahan atribut dari masing-masing dimensi.

2) Dilihat dari perspektif alat tangkap untuk semua alat tangkap yang diteliti dalam status kurang berkelanjutan. Walaupun pada dimensi sosial seluruhnya cukup berkelanjutan $(60,77)$ namun secara umum perikanan jaring rampus, bundes dan gemplo di perairan pantai Tegal ini tidak didukung oleh keberlanjutan dimensi ekologi.

3) Berdasarkan penilaian dari kelima dimensi yaitu dari dimensi ekologi, ekonomi, sosial, teknologi, dan hukumkelembagaan yang dimensi keberlanjutannya paling rendah adalah dimensi ekologi di Kabupaten Tegal sebesar 27,87 dalam selang 26 - 50 (kurang berkelanjutan bahkan mendekati skor buruk).

4) Atribut-atribut penting dan paling sensitif ini pada akhirnya digunakan untuk mengidentifikasi upaya-upaya (rekomendasi) yang dapat dilakukan untuk meningkatkan keberlanjutan perikanan di lokasi penelitian. 


\section{Rekomendasi Kebijakan}

Rekomendasi yang dapat diberikan antara lain :

1) Untuk mempertahankan keberlanjutan perikanan tangkap di wilayah pantai maka pengembangan industri perikanan diarahkan ke laut lepas dengan tetap memfungsikan wilayah pantai sebagai wilayah pengelolaan perikanan tangkap skala kecil yang konservatif. Di samping itu, kerjasama antar seluruh stakeholders pemanfaat sumberdaya perikanan termasuk kerjasama antar daerah yang berbatasan sangat diperlukan agar efektivitas pengelolaan perikanan dapat lebih ditingkatkan.

2) Perlu segera ada instrumen kebijakan untuk mengatasi keadaan sumberdaya perikanan yang sudah mengalami tangkap lebih (over exploited, dan over harvested) di Kabupaten Tegal agar sumberdaya perikanan ini tidak habis dalam jangka pendek namun tetap berkelanjutan dalam jangka panjang. Upaya-upaya pengelolaan optimal penangkapan sumberdaya perikanan agar tidak terjadi over capacity yang pada akhirnya merugikan semua pihak, menjadi suatu keharusan. Perlu adanya pengembangan upaya-upaya konservasi dari kelembagaan lokal sehingga kegiatan eksploitasi dapat diimbangi dengan kegiatan konservasi yang dapat mengurangi dampak terhadap sumberdaya perikanan dalam jangka panjang.

3) Hasil analisis atribut-atribut sensitif dari setiap dimensi (Gambar 4b, 5b, 6b, 7b, $8 b)$ dapat memberikan rekomendasi yang diperlukan. Beberapa atribut sensitif pada masing-masing dimensi yang dianalisis menggambarkan perlunya prioritas penanganan (rekomendasi kebijakan yang dapat diberikan/implikasi kebijakan) dalam meningkatkan keberlanjutan perikanan tangkap skala kecil pada masing-masing dimensi. Beberapa atribut-atribut sensitif dari setiap dimensi dan rekomendasi kebijakan yang dapat diberikan dari setiap dimensi tersebut antara lain:

\section{A. Dimensi Ekologi}

1. Discard and by catch dan Perubahan ukuran ikan yang tertangkap Peningkatan selektivitas alat tangkap yang digunakan. Dengan menggunakan alat tangkap yang selektif akan diperoleh ukuran ikan sesuai dengan kebutuhan pasar dan mengurangi risiko ikan tidak laku di pasar.

2. Tekanan pemanfaatan perairan Pengurangan limbah / sampah yang dihasilkan dari masyarakat nelayan dengan peningkatan pengetahuan dan pendidikan mengenai lingkungan perairan

\section{B. Dimensi Ekonomi}

1. Sifat kepemilikan sarana penangkapan Membatasi atau mengurangi kepemilikan modal usaha perikanan dari luar wilayah yang bersifat profit semata

2. Tingkat subsidi Penurunan tingkat subsidi yang meningkatkan effort menangkap ikan di perairan pantai yang fishing ground-nya sudah menurun tetapi diikuti perbaikan struktur harga jual ikan hasil tangkapan nelayan melalui mekanisme lelang yang transparan, pengembangan skill nelayan dalam penanganan produk perikanan untuk memperoleh nilai tambah, dll.

3. Besarnya pemasaran perikanan Wilayah pemasaran yang sudah ada dipertahankan/tidak dilakukan perluasan untuk mengurangi tekanan perairan terhadap produk perikanan

\section{Dimensi sosial}

1. Status dan frekuensi konflik Penanganan konflik baik implementasi hukum maupun ketegasan aparat 
terhadap pelanggaran yang terjadi.

2. Tingkat pendidikan Peningkatan pendidikan para nelayan agar dapat dengan cepat mengadopsi/ menyerap informasi dan penambahan wawasan s e r t a m e n i n g k t n y a ketrampilan/kecakapan hidup demi peningkatan kualitas hidup dan kesejahteraan mereka. Peningkatan pendidikan nelayan dan keluarganya menduduki posisi yang sangat strategis dalam meningkatkan kecakapan hidup (life skill) sehingga mereka lebih mampu berkompetisi dalam mencari alternatif lain dalam meningkatkan kesejahteraannya.

3. Partisipasi keluarga dalam pemanfaatan SDI Peningkatan partisipasi keluarga agar para nelayan tidak hanya mengandalkan sumber pendapatan keluarga dari tangkapan ikan namun dari bentuk lainnya, misalnya nilai tambah dari produk perikanan. Peningkatan partisipasi keluarga ini akan dapat ditingkatkan dengan berbagai cara diantaranya upaya-upaya peningkatan ketrampilan dan wawasan.

\section{Dimensi Teknologi}

1. Penggunaan alat bantu penangkapan (FADS) Pembatasan dan pengawasan penggunaan FADS. Pembatasan dimaksudkan untuk mengurangi/ membatasi besaran kekuatan lampu (FADS) yang digunakan sebagai atraktif dalam penangkapan. Penggunaan FADS dapat juga dipadukan dengan kebijakan selektifitas alat tangkap.

2. Selektifitas alat tangkap Penggunaan alat tangkap yang selektif akan diperoleh ukuran ikan sesuai dengan kebutuhan pasar dan mengurangi risiko ikan tidak laku di pasar.

\section{E. Dimensi Hukum-Kelembagaan}

1. Ketersediaan dan peran personil penegak hukum Bersama-sama melibatkan dan meningkatkan peran keberadaan tokoh masyarakat lokal dalam penentuan kebijakan dan pengawasan dalam menjaga keberlanjutan perikanan tangkap dan aspek-aspek pendukungnya.

2. Demokrasi dalam penentuan kebijakan Melibatkan para nelayan sebagai salah satu stakeholder agar kebijakankebijakan yang telah dibuat tidak lagi misleading terhadap pengelolaan dan pemanfaatan sumberdaya perikanan.

\section{DAFTAR PUSTAKA}

Badan Pusat Statistik Kabupaten Tegal. 2003. Kabupaten Tegal Dalam Angka 2003. Kantor BPS Kabupaten Tegal.

Badan Pusat Statistik Kabupaten Tegal. 2004. Kabupaten Tegal Dalam Angka 2004. Kantor BPS Kabupaten Tegal.

Badan Pusat Statistik. 2003. Statistik Indonesia 2003. Kantor BPS Pusat.

Charles, T. 2001. Sustainable Fishery System. Blackwell Science. UK.

FAO. 1995. The Code of Conduct for Responsible Fisheries. FAO of The United Nations. Rome.

FAO. 1999a. Rapfish : A Rapid Appraisal Technique For Fisheries, And Its Application To The Code Of Conduct For Responsible Fisheries. Rome : $\mathrm{FAO}$

FAO. 1999b. Indicators for Sustainable Development of Marine Capture Fisheries. FAO Technical Guidelines for Responsible Fisheries. FAO of The United Nations. Rome.

FAO. 2001. Indicators for Sustainable Development of Marine Capture Fisheries. FAO Technical Guidelines for Responsible Fisheries. No. 08 Food and Agriculture Organization (FAO) Rome. 
Fauzi, A dan Anna, S. 2005. Pemodelan Sumber Daya Perikanan dan Kelautan. Jakarta: PT. Gramedia Pustaka Utama.

Fauzi, A. 2002. Penilaian depresiasi sumberdaya perikanan sebagai bahan pertimbangan penentuan kebijakan pembangunan perikanan. Jurnal Pesisir dan Lautan Vol. 4 (2). pp: 36-49.

Google earth tanggal akses 24 Juli 2007.

Hermawan, M. 2006. Keberlanjutan Perikanan Tangkap Skala Kecil. Disertasi. Sekolah Pascasarjana Institut Pertanian Bogor. Tidak dipublikasikan.

Kavanagh, P. 2001. Rapid Appraisal Of Fisheries (Rapfish) Project : Rapfish Software Description (For Microsoft Excel). University of British Columbia, Fisheries Centre, Vancouver.

Kusumastanto, T. 2000. Kuliah Ekonomi Sumberdaya Alam dan Lingkungan (Tidak dipublikasi). Program Pascasarjana SPL-IPB. Bogor.
Pitcher, T. J., A. Bundy, D. Preikshot, T. Hutton, and D. Pauly. 1998. Measuring The Unmeasurable: A Multivariate And Interdisciplinary Method For Rapid Appraisal Of The Health Of Fisheries. Dalam T. J. Pitcher, P. Hart, dan D. Pauly (editor): Reinventing Fisheries Management. Kluwer, London.

Pitcher, T.J. and D. Preikshot. 2001. RAPFISH : A Rapid Appraisal Technique to Evaluate The Sustainability Status of Fisheries. Fisheries Research Report, Fisheries Center University of British Columbia, Vancouver.

Susilo, S. B. 2003. Keberlanjutan Pembangunan Pulau-Pulau Kecil : Studi Kasus Kelurahan Pulau Panggang Dan Pulau Pari, Kepulauan Seribu, DKI Jakarta. Disertasi. Program Pascasarjana Institut Pertanian Bogor.

Smith. I. R. 1979. A Research Framework for Traditional Fisheries. ICLARM Studies and Reviews. 2:40p 